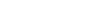

\title{
Collective memory and the populist cause: The Ulucanlar Prison Museum in Turkey
}

Memory Studies 2021, Vol. 14(5) II 106-II 26 (C) The Author(s) 2021 Article reuse guidelines: sagepub.com/journals-permissions DOI: $10.1177 / 17506980211033334$ journals.sagepub.com/home/mss

\author{
Meral Ugur-Cinar (D) and Berat Uygar Altınok \\ Bilkent University, Turkey
}

@SAGE

\begin{abstract}
This article focuses on how political actors appropriate the past by utilizing collective traumas for their populist cause. We demonstrate how the Ulucanlar Prison Museum in Turkey and the oppression of military interventions, for which it served as a backyard, became a tool for the AKP's (Adalet ve Kalkınma PartisiJustice and Development Party) populist agenda. Through a particular narration of history embedded in the museum, the AKP aimed to forge an internal frontier within the society between an envisioned homogenous body of people on the one hand and the elite on the other. Situating itself as the people's authentic voice against this elite, the AKP tried to further its popular appeal and legitimize its extension of power. What appeared as coming to terms with the past was instead the instrumentalization of the past for a singular political agenda, eager to remove the complexities and pluralism of the past for the sake of telling a politically useful story.
\end{abstract}

\section{Keywords}

collective memory, museums, populism, trauma, Turkey

This article explores the populism and collective memory nexus through the case of the Ulucanlar Prison Museum in Ankara, Turkey. We look at how through the Ulucanlar Prison Museum, the Justice and Development Party (Adalet ve Kalkınma Partisi-AKP) stylized traumatic aspects of Turkish history in order to further its populist appeal and extend its power base. While the existing literature gives us invaluable insight into the role of collective memory in the construction and contestation of political identity (see, e.g. Art, 2006; Assmann, 1995; Berger and Niven, 2014; Eyerman, 2004; Kansteiner, 2002; Olick, 1999; Zerubavel, 1995), the relationship between populism and collective memory has so far not received sufficient attention. ${ }^{1}$

Populism, whose main elements are a Manichean anti-establishment discourse, vertical ties to a leader by-passing institutions, and a mass support base, ${ }^{2}$ is simultaneously an associative and

\section{Corresponding author:}

Meral Ugur-Cinar, Political Science Department, Bilkent University, Main Campus, Faculty of Economic and Administrative Sciences Building, 06800 Çankaya, Ankara, Turkey.

Email: meral.ugur@bilkent.edu.tr 
disassociative form of politics. It is associative since the construction of a homogenous people in moral terms is essential, which often relies on the narration of the past. It is disassociative because the Manichean rhetoric embedded in its formulation requires an internal frontier constitution among the heterogeneous population. In the hands of populists, collective memory does not only serve as a device to consolidate a sense of community, but it also defines the limits of inclusion. By framing histories of political violence in terms of collective trauma, populist politics forges an internal frontier among society to establish an "us-versus-them" dichotomy. The boundary of "the people," which is envisioned as a homogenous entity, relies thus heavily on the past's instrumentalization to delineate who can be included and who should be excluded from the collectivity.

Whether populism is a desirable corrective to democracy or a detrimental force against it, is a hotly contested issue, particularly among the Left. For some, most famously, Laclau (2005) and Mouffe (2018), a left-populist alternative can provide a means for emancipatory politics by the mobilization of hitherto excluded groups. We agree with De la Torre (2019) that even though left populists might be right about populism being able to point at the existing regimes' deficits, their solutions are detrimental to democracy. Populists may indicate the problems of current regimes such as issues of representation or inequality. Yet, their damages far outweigh their benefits. Populism targets institutions such as checks and balances mechanisms as well as pluralism in civil society. It also leads to further polarization that can make democratic politics unworkable and may even lead to civil war due to its Manichean lens of societal cleavages. ${ }^{3}$

Similarly, while a project that tries to pick up the cause of the excluded and come to terms with the past and all its wrongdoings can be regarded as a commendable effort, doing this in a populist manner has the potential to cause more harm than good, as the case in hand will also reveal.

The core of the problem lies in the denial of pluralism and the claim that the actors of the populist project, particularly the leader, stands as the sole representative of the people. As Müller (2016) maintains, populists are anti-pluralist and claim to be the exclusive representatives of a homogenous unity of people whom the populist leader embodies. Just as politics is reduced to a moral battle between a homogenous body of people and "the others," history (and memory) is also flattened to a unilinear one-dimensional narrative at the expense of the true complexity of the past.

All memory is selective, and as Barthes (1981) and White $(1973,1978,1990)$ note, history writing has a literary character in which more than one plausible emplotment is possible. In that sense, it is not so much the selective nature of remembering but the reductionist, one-dimensional presentation of history that does injustice to the memories of those involved and thereby depicts a reductionist narrative of Turkey's recent history in line with the propagated populist project. As we will show, the storytelling in Ulucanlar is a populist one; it serves the political project of the AKP regime and its efforts of presenting the ruling party as the people's sole representative. Ulucanlar Museum's populist storytelling as we will show throughout this article, presents a homogenous body of perpetual victims waiting to be salvaged by the AKP.

Unlike individual memory, collective memory has its own dynamics, necessitating it to be studied accordingly (Kansteiner, 2002; Olick, 1999; Wertsch and Roediger, 2008). Given the mediated nature of collective memory (Wertsch, 2000), museums can be understood as crucial sites through which the past is deployed for populist mobilization efforts. Like other public mediums such as mass media, monuments, literature, and cinema, museums are essential in constructing social relationships that attach meaning to certain historical moments, traumas, and artifacts. ${ }^{4}$ What is more, the authenticity of the materials exhibited grants museums further authority in producing and reproducing collective memory. 
Ulucanlar, an infamous prison strongly associated with tortures and executions, was turned into a museum between 2009 and 2011, a critical period during the AKP's populist rule whereby ideological clashes between the military and judiciary elites and the AKP were at its peak. The museumification of the Ulucanlar Prison and the debates surrounding this process provide an exemplary case of the AKP's reimagining of time and space to advance its counter-hegemonic populist cause. This article will examine the construction of this populist discourse via the instrumentalization of collective memory in general, and collective trauma in particular through an in-depth analysis of the establishment and fashioning of the Ulucanlar Museum.

\section{The AKP and populism}

The "other" is as essential to constructing a populist narrative as the "us." In the Turkish case, the secular-religious divide informed the us-versus-them distinction in the populist narratives. The populist right in Turkey has a long history in capitalizing on the secular-religious divide, which is seen to overlap with the center-periphery divide since the formative years of the Republic: the ruling elite is presented to have pushed for the secularization of the public life, which was met with resistance from many sectors of the society who were more religious than the revolutionaries (Mardin, 1973; Özbudun, 2013; for a critical review, see Bakiner, 2018).

The AKP's populism has made use of the dominant cleavage structure in Turkey and has presented itself as the voice of the periphery, which it claimed, has been repressed by the Kemalist elite and the political establishment. The AKP was founded in 2001 as a result of a split within the Islamists in Turkey. Its founders liked to call themselves "conservative democrats" and claimed that, different from other political Islamists, they were pro-democracy and human rights. The AKP came to power in 2002 and remains the ruling party in government since. From its inception, the party has situated itself as the true representative of the people against the elites. Under Erdoğan's rule, polarizing the secular-religions division has turned into a grand strategy used in every possible instance and increasing tone over the years. For Erdoğan, the pious people constitute the "us," while the secular elites constitute the corrupt, alienated, and despotic "other." Secular politicians, but especially the military and judiciary, which have, until the 2010 s, seen themselves as the guardians of the Republic and Atatürk's revolution, are the main targets of this populist formula. They are characterized as the impediments to the will of the pious Turkish citizens, that is, the so-called authentic people. In parallel, the Ulucanlar Museum was designed as a site that shows the brutality and the aloofness of the elite.

Intense victimization is evident in how the AKP narrates the Republic's history. It is most evident in Recep Tayyip Erdoğan's speeches, who urges the younger generations not to forget their victimization and even hold on to their grudges (Birgun, 2020). Furthermore, in line with populism, the AKP is pushing for a majoritarian, plebiscitary notion of democracy. Democracy is defined as the will of the people that can only be performed on election days but is otherwise spoken for by the leader himself. What is more, again echoing the populist spirit, the people are envisioned as faceless masses, rather than a heterogeneous body of citizens with plural identities, interests, and preferences.

In addition to constant crises between the AKP and the establishment, there were critical episodes when tension reached a crescendo. Drawing on Öniş (2015), Aytaç and Elçi (2019: 94) divide the AKP rule into three eras: 2002-2007, 2007-2011, and 2011 to present. The first period is known for a pro-EU agenda and steps in democratization; the second period shows severe signs of decline in democratization momentum, whereas the third period is when the AKP became increasingly authoritarian in its rule. The second period, which is the one in which the founding of the Ulucanlar Prison Museum falls, witnessed a "critical showdown between the AKP and the 
military and judicial elites." (Aytaç and Elçi, 2019: 94). Critical occurrences in this regard include the secularist-Islamist clash surrounding the 2007 presidential elections, which led to the constitutional change that enabled the election of the president via popular vote as well as the Constitutional Court case the same year, in which the AKP was saved from getting closed by a mere single vote. The 2007 was also the year when Ergenekon trials started. With this, the AKP-backed prosecutors started mass investigations against active and retired members of the military and secularist civil and political actors on the grounds of plotting a military intervention. These investigations, which lasted until 2013, turned into a witch-hunt and an eventual reconfiguration of the military significantly.

Once the attacks on the military establishment had started, the AKP turned to the state's high courts to redesign them. In 2010, the AKP introduced a series of constitutional amendments to reengineer the judiciary. Short of the number of seats required to amend the constitution in the parliament, the AKP brought the issue to the people in a historical and very polarizing referendum of 2010. Presented as a giant step of democratization by the AKP due to some minor reforms in civil rights and limits to the power of the military and judicial establishment, what the amendments intended to do was actually to redesign the military and judiciary in the AKP's favor. During the campaigns, the AKP framed the proposed changes as struggles against tutelage and a confrontation with the 1980 military intervention's legacy, symbolically putting the referendum on the anniversary of the 1980 military coup on September 12. The date "September 12" is used simultaneously as a synecdoche for the 1980 military coup in Turkey. During the campaign, the then Prime Minister Erdoğan summarized how the AKP framed the campaign: "We are saying 'yes,' to confront September 12, to remove the immunity on September 12. We are saying 'yes' so that we never face any other coups in this country, so that the future of this country will never be darkened and so that democracy will not be put on hold. We are saying 'yes' for a grand Turkey, a strong Turkey, and a prestigious Turkey" (BBC Turkish, 2017). Framing the discourse in these terms has been influential on some segments of the society outside the AKP's power base as well, which is also evident in the referendum's result. With Kurds boycotting the referendum, the AKP reached a yes vote of $58 \%$.

During this campaign, Erdoğan made use of historical figures executed in the hands of the 1980 military junta at the Ulucanlar Prison. A case in point is the letter Erdoğan read in the parliament weeping, written by the far-right militant called Mustafa Pehlivanoğlu, who was executed by the junta. Pehlivanoğlu wrote the letter to his father as a farewell. Erdoğan read this letter out loud as part of his campaign to persuade voters to cast "yes" for the proposed constitutional amendments discussed above. In the same speech, Erdoğan also recited a poem written by the poet Nevzat Çelik (later turned into a famous protest song by the singer Ahmet Kaya) for Necdet Adal1, a leftist youth leader also executed at Ulucanlar. Erdoğan also mentioned Erdal Eren, again from the Left, explaining that Eren was hanged by the junta despite being only 17 years old. In addition to this, Erdoğan read a poem by the far-right youth leader Muhsin Yazıcıoğlu, who stayed at Ulucanlar as well as the Mamak prison. The long list of names mentioned by Erdoğan in his speech also included historical figures known for being religious, having suffered at the junta's hands. After listing all these names from different political convictions, Erdoğan concluded as follows: "Exactly at the 30th anniversary of the coup, we will settle our accounts with the tortures, cruelty, and inhumane practices. We will come to terms with the death of the youth, with the untimely farewells, and with the mentality that carried 17-year-old children to the gallows." (Haberturk, 2010)

The choice of Ulucanlar Prison as a focal point of collective trauma for the AKP at this critical turning point in Turkish history is deeply embedded in the prison's past. What makes Ulucanlar a precious tool in the AKP's toolkit for its struggle against the Kemalist establishment is its history of executions of political prisoners - first in the hands of the revolutionary courts in the formative 
years of the Republic and then in the hands of military juntas. Ulucanlar was built in 1925 as the first prison complex of Turkey, 2 years after the Republic's proclamation. Being a remand prison, inmates were often kept in Ulucanlar for a brief amount of time, sent there either for short-term imprisonment, for transfers to other prison facilities, or notoriously for their death penalties. Eighteen people were hanged in Ulucanlar Prison, 17 of which were political prisoners. Most of the executions and torture were sanctioned under the military or semi-military rule, either through the Independence Tribunals of the 1920s or the military interventions of 1971 and 1980. In our interview with her, the museum's curator Merve Bayiksel emphasized that in creating this museum, they wanted to focus on the early Republican era and those who were hanged after military interventions. In another interview, she told Doroll (2015: 206) that the museum was focused on telling the stories of those in prison because of their ideas rather than ordinary prisoners. Adding that the museum ostensibly serves as a symbol of how democratic Turkey has become today, she claimed that, "In Turkey's past, people were imprisoned for their ideas, this does not happen in Turkey today," a highly questionable point which we will elaborate on in the conclusion.

The prison also housed many notable political prisoners across the political spectrum, such as politicians, intellectuals, famous poets, journalists, iconic youth leaders and so on. The AKP perceived this fact as a source of leverage against the Kemalist establishment, embodied in the form of military and judiciary elites. The executions of the most famous revolutionary youth leaders Deniz Gezmiş, Yusuf Aslan, and Hüseyin Inan were imprisoned here after the 1971 military intervention. Erdal Eren, whose age was increased to 18 due to the judiciary's lack of due process under the military junta to be hanged, was also executed hereafter the 1980 coup. Iskilipli Atıf Hoca, a religious figure who challenged the Republic's reforms, was hanged in a square in Ulus, away from the prison in 1926, but was also counted amongst those executed here (Batuman, 2011). The execution of far-right militants Fikri Arıkan and Ali Bülent Orhan following the 1980 coup d'etat also took place at Ulucanlar.

Hence, the museum provided a crucial opportunity to push the AKP's populist agenda by portraying the ruling regime as the people's genuine voice and the periphery's democratizing force against the established center, which was brutal and aloof to the realities of the people. The museum provided an excellent opportunity for the AKP regime to narrate the Turkish Republic's history as one in which people were brutally repressed because of their disagreement with the status quo. However, by reducing the prison's past to a one-dimensional oppressor-victim narrative, the museum project resulted in multiple injustices to the memories of those involved and created a rupture with the past that did not leave any room for contemplation of contemporary injustices and wrongdoings of the AKP's authoritarian rule.

\section{The Ulucanlar Prison museum in context}

Ulucanlar Prison Museum is located in Turkey's capital city, Ankara, once a small town during the late Ottoman era. When the war of independence started in 1919, Ankara became the heart of the struggle for a new beginning, as evident with the National Assembly being founded in Ankara under Atatürk's lead. Throughout its history as the country's capital, Ankara has been the object of different political visions as its landscape, architecture, and lieux de mémoire (Nora, 1989) have changed accordingly. After the Republic's proclamation in 1923, Ankara became the center of attention for the Republican elite. Since Istanbul was loaded with Ottoman symbols and its Islamic, monarchical past, Ankara offered a clean canvas for the new Republican project to create a capital city akin to its Western counterparts. With its historical figures, myths, and commemorations, the Ottoman past was taken to the forefront once the AKP and its forerunners came to power (Kaya et al., 2020). From 1994 until 2019, political Islamist parties ruled Ankara's metropolitan 
municipality and many local municipalities, starting with the Welfare Party, the AKP's predecessor. Perhaps the most telling example of the hegemonic struggle between the secularists and Islamists is the change of Ankara's city emblem from a stylized version of the Hittite sun disk (alluding to the pre-Islamic roots of the Turks in the early official history of Turkey) to an emblem with a mosque silhouette in 1995 (Batuman, 2013: 585). ${ }^{5}$

The Altındağ Municipality of Ankara, where the Ulucanlar Museum is located, lies within the Ulus district. Ulus (literally meaning, the nation) was the focal point for the Republic founders, who aspired to shape it following a Western and secularist vision (Yalım, 2002). The Republic's first and second parliament buildings are located in this district, currently serving as museums themselves. Ulus is no stranger to museums, as the world-famous Anatolian Civilizations Museum and other museums established during the Republic's early period, such as the Ethnography Museum or the Sculpture Museum, illustrate. In contrast to such museums that either focus on the pre-Islamic history of the area or serve as pedagogical instruments to orient the citizens into Western-style arts, especially with the rise of the AKP's power, significant additions, and interventions have been made to Ulus to impose a more religious, nativist, and conservative image to the place and to project a counter-hegemonic national imaginary. These include the museumification of the conservative poet Mehmet Akif Ersoy's house and the establishment of the Intangible Cultural Heritage Museum, which provide an alternative pilgrimage root, as it were, to the Republican imaginary. Combined with the gentrification and renovation project of the historical Hamamönü area, where especially during Ramadan, Ottoman style festivities are held, and the building of the Melike Hatun Mosque with 7000 prayer capacity as well as the expansion of the surroundings of the historical Haci Bayram Mosque, Ulus is at the center of the AKP's rebranding of Turkish collective memory and official history.

The events surrounding the Ulucanlar Prison museumification reveal that its acute incorporation into the AKP's populist agenda owes to the fact that the AKP found the prison at its disposal when it was about to roll out its counter-hegemonic populist agenda. As Turkey entered a new phase in building carceral facilities reducing the numbers of inmates in the cells, the Ulucanlar Prison closed down in August 2006 after transferring inmates to a newly constructed facility in Sincan, Ankara (Cengizkan and Cengizkan, 2019; Koç and Yavuz, 2010; TMMOB Mimarlar Odası Ankara Şubesi, 2010). Contestation on the future of the prison site started immediately as it became evident that the metropolitan municipality of Ankara intended to demolish the building and turn the area into a shopping mall.

In December 2006, the Ankara branch of the progressive Chamber of Architects and Engineers (Türk Mühendis ve Mimar Odaları Birliği, TMMOB in Turkish) formed a team of experts and started to document the site with official permissions from Justice Department. Upon this archival work, which remains the most comprehensive one on the site, TMMOB then applied for the official protection of the site. The application was the outcome of specification of several buildings in the site as fulfilling criteria set by the Law of Protection of Cultural and Natural Assets (Kültür Ve Tabiat Varliklarini Koruma Kanunu) for being considered as tangible cultural heritage. In accordance with the law, the site met architectural merits by being representative of late Ottoman and early Republican architectural forms and style and for being located in Ulus, at the center of the newly established capital, Ankara, as well as for being representative of the periods" "social, economic, and cultural changes through architectural expressions" (TMMOB Mimarlar Odası Ankara Şubesi, 2010).

A meeting between TMMOB and the Ministry of Justice on the site's possible future resulted in the National Architecture Students' Ideas Project. In April 2007, 79 projects by undergraduate and graduate-level architecture students were submitted for the prison's museumification. In the same month, the Committee for Protection of Cultural and Natural Heritages in Ankara certified the site 
as a cultural and urban heritage. Later in that May, competition results were announced for the winning project.

Initially, a protocol was signed between TMMOB Ankara Branch, Ankara Bar Association, Ministry of Justice, and the Altındağ Municipal government for overseeing this project. Yet, the AKP-run Altındağ municipal government gradually excluded TMOBB from the restoration and presented itself as the sole actor of the process. Members of TMOBB were primarily concerned with the Altındağ municipality's decisions to tear down some parts of the museum and make renovations that were not in line with the historical building's authenticity. For example, the prison courtyard, which was ordinarily dark and narrow, was made brighter and more spacious due to the demolition of some parts of the building. Municipality's plans introduced cafeterias, movie plateaus, and other commercial enterprises, which further removed the space from the past's actual experiences. ${ }^{6}$ Once members of TMMOB voiced their opposition to such decisions, the municipality gradually cut them off and eventually stopped all communications with them (Mimdap, 2012). As stated by the TMOBB members in an interview, even in the brochures published by the Altındag municipality, the museum's history started from the year of 2009 , thereby deliberately not giving any credit for TMOBB's efforts.

Even though the AKP was not motivated in turning the prison into a museum from the onset, it found Ulucanlar as a fitting site to put forward its political agenda that culminated in the 2010 referendum discussed above. Step by step, the original actors of the museumification were excluded from the process, leaving the museum at the discretion of the political will. Ulucanlar Prison Museum was framed as a place of truth reconciliation and as a place of reflection, but the outcome was far from that.

\section{Ulucanlar Museum in action: Remembering violence, torture, and death}

The Ulucanlar museum commemorates a wide range of political prisoners consisting of artists, journalists, politicians, and activists as a memorial museum. But more so, it serves as a trauma-site museum (Violi, 2012) since the exhibition itself is grounded on the site's testimony and witnesses of political violence. The display focuses on carceral practices of the past, such as torture, abuse, and capital punishment (Figures 1 and 2). The scope and diversity of the political violence of the site's 81 years-long function as a carceral institution effectuates the master-narrative of the display. In each case, the museum's representation indicates the convicts' innocence and highlights the unjust procedures of the incarcerations, trials, and executions.

The testimonial power of trauma site museums resides with their capacity to "maintain a real spatial contiguity with the trauma itself" (Violi, 2012). As Violi (2012) illustrates in her analysis of the trauma site museums of Tuol Sleng, Villa Grimaldi, and Bologna Ustica, a direct link with the past is established in museums built right on the spot at which the traumatic events happened. This direct link is due to the indexicality of the place and via the objects presented in the museum. The traces and imprints in the place, Violi argues, embody the event's memory and thereby provide a direct connection to the past.

The executions of political prisoners constitute the foci of the Ulucanlar Prison Museum as the very site on which these executions took place. The indexicality of the trauma site is further reinforced by the use of personal items of these inmates. Those who were executed by the military junta as well as their personal belongings and original materials directly linked to their execution at Ulucanlar, take center stage in the museum. The museum displays the junta victims' personal belongings, ranging from farewell letters to family members to clothing worn in prison and pictures taken when they were captured (Figures 3-5). 
A case in point is the commemoration of those who were executed by the Independence Tribunals: İskilipli Atıf Hoca and Ali Riza Hoca, two religious figures who were hanged for crimes against the newly established Republic as well as five other people who were executed for plotting an assassination attempt against Atatürk and charged with treason and dismantling the constitutional order. The display and the museum's printed publications repeatedly emphasize anecdotes regarding these prisoners' last moments and showcase items such as their letters to loved ones. One of the unique sets of items due to its proximity and actual witnessing of the event is the display of the tags hung on the necks of revolutionary youth activists Deniz Gezmiş, Yusuf Aslan, and Hüseyin İnan at the time of their execution in 1972. Another such example is the letter the mother of the ultranationalist Fikri Arıkan wrote to him.

The use of media such as personal items, letters, and anecdotes aims to serve multiple purposes. First, it aims to give the visitor a sense of authenticity, enhancing the museum's authority, and validating its own existence (Thurston, 2016: 12). ${ }^{7}$ The museum, which is already in a position of exerting its presentation in an authoritative tone due to the indexicality of its very location, furthers this attempt to be the bearer of authentic knowledge by using primary material belonging to the inmates. Besides, the museum also tries to facilitate a personal connection between the visitor and the former inmate at the national level. Family tropes, domestic clothing items, particularly knit sweaters, serve to build a bond between the visitor and the inmate that is built at the national, almost folkloric level. To this end, sculptures in common wards display everyday activities such as reading the Qur'an and other books, playing backgammon, drinking tea. Wax sculptures and background music, which consists of a playlist of prison-themed songs and sound effects, aim to enhance the ambiance.

The impact of the trauma site turned museum is enhanced by the pathemic interventions to the place (Violi, 2012: 44), as is the case with the recorded torture sounds or the placing of the wax sculptures in particular ways in the cells. Torture and violence are highlighted in the museum through wax sculptures in the isolation cells situated in distressed positions and mostly accompanied by mice. Torture sounds can be heard from the isolation cells. One can hear the sounds of the inmates and the perpetrators in imaginary dialogues coming from the cells. By paying an additional fee, one could even experience a cell by being locked up in it for a certain amount of time, though this practice has been abandoned due to visitors' volume (Aysu, 2015: 27). The desperate positions in which wax sculptures are shown, the inclusion of items shaped like mice, and torture sounds are meant to invoke in the visitor visceral feelings and a particular first-person experience and understanding of the prison. Museum's display aims to evoke a particular feeling of the past, one based on remembering the atrocities of political violence. It also aims to assure the visitors that these visceral and intense feelings the museum summons in the visitors are confined to the past and that one ought to be grateful and content with the present regime, as will be shown in our discussion of the gallows put behind the bar.

The area where mice and torture sounds are present also serves as a backstage to the other areas of the museum, such as the wards, which display the prisoners' everyday lives. This area is designed as a "backstage" to the lives in prison and aims to further enhance the museum's sense of authenticity by supposedly letting visitors into the dark and previously inaccessible parts of the prison. This division between front stage and backstage is based on Irving Goffman and is introduced by MacCannell (2013) to the sociological analysis of tourism, demonstrating how museums devise this strategy of giving the visitor the sense of entering the backstage in areas which are carefully staged in actuality as front stages. Walby and Piche (2015: 231), in their analysis of 45 penal history sites across Canada, bring a further nuanced account to the backstage-front stage division by showing that these two can best be considered as a continuum rather than a dichotomy in museums, which is used by staff and volunteers in such museums to reinforce the "purported realities of incarceration." In the case of Ulucanlar, such representations do not just attempt to fulfill the 
visitor's need for an authentic experience. They also play crucial political roles in inviting visitors to share the curated sensory experience so as to complete the populist pilgrimage route by identifying trauma, victimization, the perpetrator, and the savior in their singular forms.

By using original sources to establish a feeling of authentic experience and identifying the former inmates with the visitors, thereby contributing to the populist political project, the museum tells a narrative that reaches its climax with the original gallows' display and hangman's knot. The way the museum is configured makes the visitors follow a specific route before reaching the gallows at the end of this tour, even though this area is actually located closer to the entrance in its original form. Visitors see the isolation cells with the sounds of torture, the wards exhibiting wax sculptures and personal items of inmates, and historical newspaper clips covering coup d'etats or prison riots before they reach the final display - the gallows. Dramatically, the gallow is put behind bars. The placard on the bar reads: "Death Penalty in Turkey was removed entirely by the Decree no: 5218 of National Assembly in 14.07.2004." What is more, the museum's website proudly declares, "We put the death penalty behind bars (Figure 8)."

As the above analysis has shown, the materiality and structure of the display and, the narrative surrounding the museum exhibit attempt to build a "prosthetic memory" in which a person "takes on a more personal, deeply felt memory of a past event through which he or she did not live" (Landsberg, 2004: 2). Walby and Piche (2015) argue that:

\footnotetext{
"the staging of authenticity not only makes meaning out of stone-cold walls and steel bars but can also contribute to the erasure of possible counter-narratives about imprisonment and punishment. Beyond further analyzing the strategies for and forms of staged authenticity, future research should examine how staged authenticity introduces silences and blind spots in the historical record, as well as in material culture" (pp. 243-244).
}

In the same vein, the next section will focus on what was gained and what was lost with the crucial interventions in the museum's configuration and their implications for the memory-populism nexus.

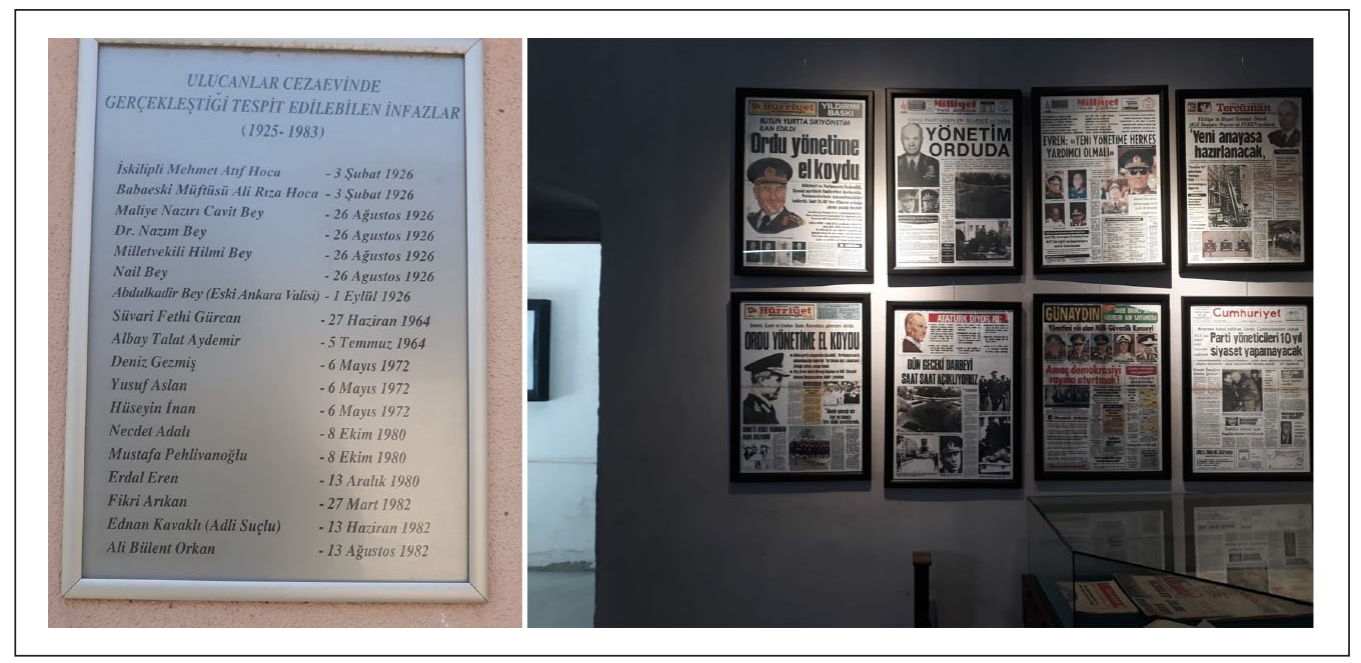

Figure I. Placard showing the names of those who were executed at Ulucanlar.

Figure 2. Newspaper clippings of military interventions framed and hung on the walls of the museum (All pictures in this article were taken by the authors). 


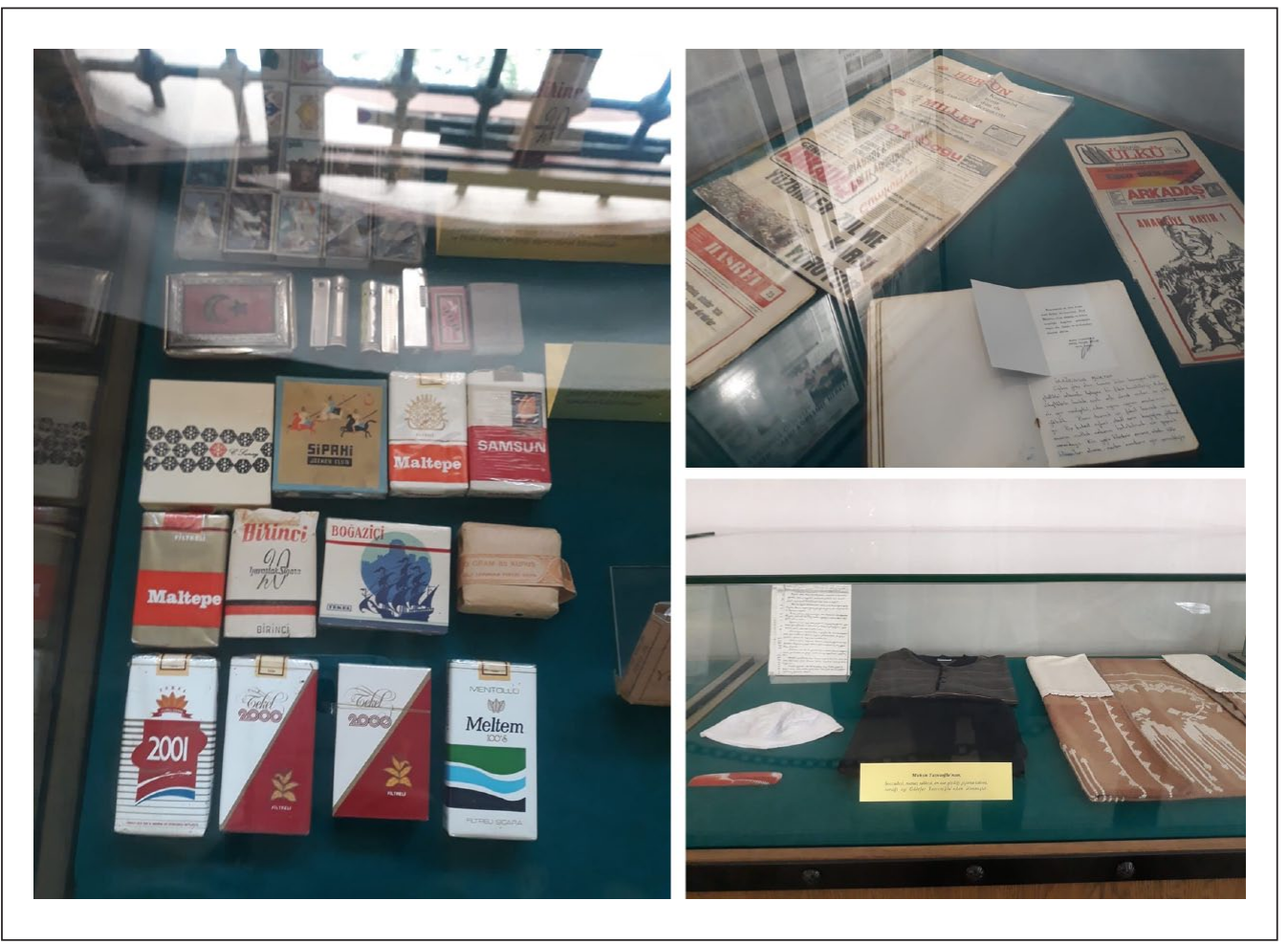

Figure 3. Packs of cigarettes of inmates.

Figure 4. Newspapers and notes of inmates.

Figure 5. Prayer rugs and personal clothing of inmates.

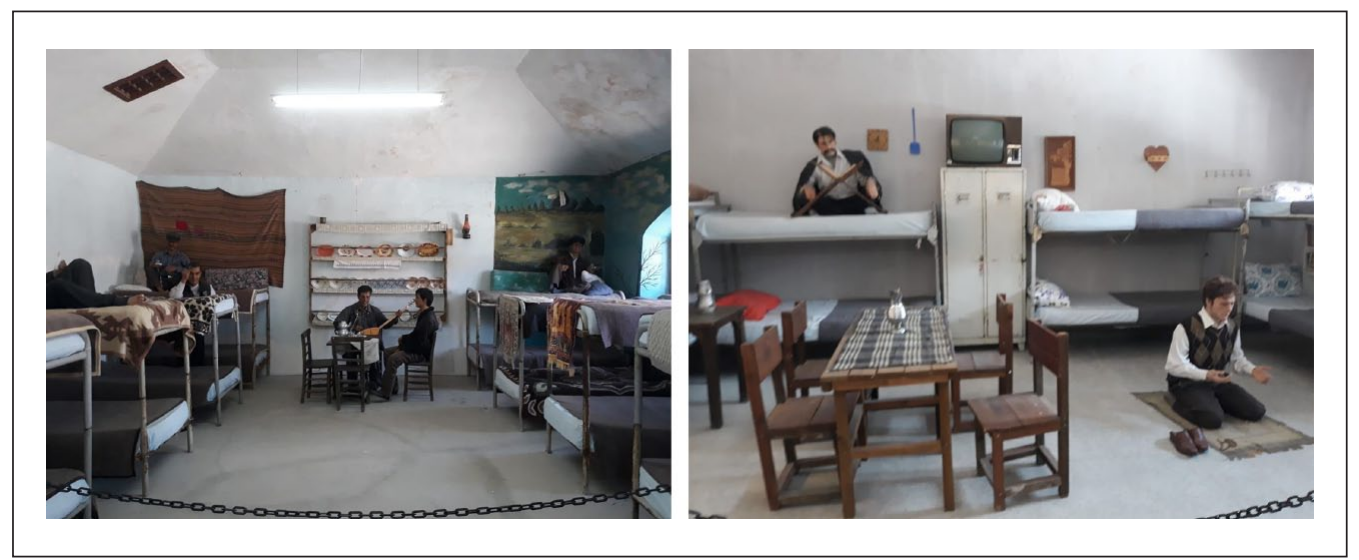

Figure 6. Wax sculptures depicting inmates in they daily lives.

Figure 7. Wax sculptures depicting inmates in they daily lives. 


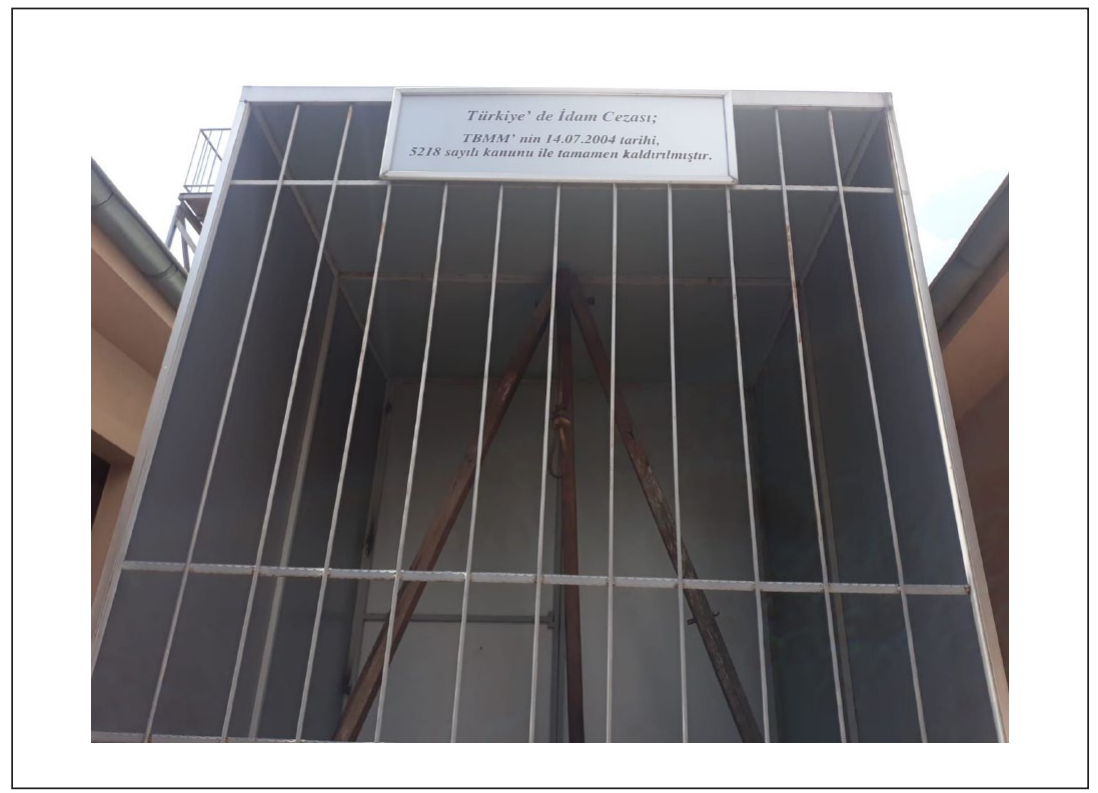

Figure 8. The gallows put behind bars.

\section{Remembering and forgetting at the crossroads of collective memory and populism}

The AKP provided a selective account of the prison's past to construct a collective trauma that fit its political agenda, leaving out essential parts of the prison's history and that of the Republic. To begin with, the way the museum put former inmates on display followed a logic that washes away the particularities of the inmates and the political causes they stood for. In fact, the victims of political violence in the display are quite diverse in their political alignments. Some were charged with crimes ranging from armed assault to writing books that are in conflict with the official Republican ideology. The museum's display tackles this diversity by a narrative that homogenizes these groups of people while emphasizing their different political alignments in a particular way. The display's master-narrative appropriates differences between the personal histories in quite a tokenist fashion: marking their alignments to the left or right-wing politics as a matter of heterogeneity of the scope of political violence by the perpetrators while at the same time constituting a narrative on bare victimhood that unifies these different experiences of political violence. The Left and Right are mentioned in the museum to show that the former establishment targeted people across the political spectrum. Yet, the complexity separating these different groups or the complex political context under which they operated or the conditions of their factionalization does not get any citation in the museum exhibition. What happens is their diversity is flattened into a victimization narrative, as will be elaborated further below.

Innocence and victimhood are the most recurring themes of the exhibition. ${ }^{8}$ The display constructs a common denominator of victimhood, in which political prisoners are transformed into a depoliticized unity pitted against the perpetrators. The depoliticization process follows a populist discourse, aligning the victim-perpetrator dichotomy with the people versus establishment axiom. 
The prisoners are depicted as mere victims whose shared political traumas mark the internal frontier's limits drawn by populist politics. The victims in the museum become synonymous with the people at large, memorializing a shared experience that molds different segments of society into one totality in which remembrance is only possible through a shared victimhood.

The museum's interventions to historical reality need to be evaluated within the political context explained earlier. As Batuman (2011) notes, with the referendum of September 12, 2010, rising on the AKP's agenda, the ruling party also instrumentalized the Left's memories as well. Ulucanlar portrayed some of the high profile, iconic youth leaders of the Left, yet narrated the story so that the leftists were just one group among the many, along with the ultranationalists and Islamists victimized by military regimes. Judging by the way the museum was curated, visitors of the museum could quickly think that the communist poet Nazim Hikmet and Necip Fazil, an icon for the Islamists, stayed together in the same ward, sleeping next to each other on adjacent bunker beds (Batuman, 2011) (Figures 9 and 10).

Political figures are therefore, stripped from their ideas and from the causes they fought for. The museum does not tell the visitors what these people's ideas were or why they were viewed as crimes by the authorities. The political alignments of the prisoners are reduced to Left or Rightwing positions. Not much content is provided about the politics of the time of the executions (Figures 11 and 12). The exhibition includes short biographies of prisoners that mention brief information about the inmates, which years they had been in Ulucanlar Prison, and the penal code they breached. The names of these historical figures are cited to make use of their celebrity status, and the museum aims to create the illusion that it is exhibiting all sides equally. The atrocities and violence faced by the Left under the Cold War conditions that encouraged the junta members is unprecedented. The depiction of the museum therefore trivializes this experience and rips it out of its context. The only place where we learn about the daily lives of the people who stayed in these wards is through the displays of the inmates' personal belongings and their depictions as hyperreal wax sculptures. The museum prides itself on the fact that all exhibition items are original. Wax sculptures in the wards and the isolation cells show inmates in their daily lives. In the wards, inmates are being depicted as drinking tea, playing saz, a Turkish folk music instrument, reciting the Qur'an, or praying on a prayer rug (Figures 6 and 7). A playlist featuring both leftist and rightist songs on prison experiences are played in the museum. As Aysu (2015: 37) also observes:

"Display of kitchen utensils, music instruments, backgammon and the like, on the one hand, offers a "humanized" representation. That is, the inmates are given life, but this life is a specific form of life. They eat, play, make, and listen to music. However, on the other hand, such representation deprives them of their political content."

Ulucanlar is pushing a celebration of a democracy that is plebiscitary, just as it fits populism. Instead of configuring citizenship as inherently plural with unique characteristics of different political convictions, the museum's overarching narrative relies on folkloric tropes that project the people as a homogenous entity.

The gallows' strategic display and the framing of the abolition of the death penalty as an achievement solely credited to the AKP also serve the populist purpose, this time in a more overt fashion. The final execution in the Republic of Turkey took place in 1984. Steps to removing the death penalty started before the AKP's rule. Turkey was in negotiations with the EU, and the removal of capital punishment was compatible with the trajectory Turkey was heeding. By 2004, the death penalty had not been in use for 20 years. Nevertheless, the image of gallows behind bars is quite a powerful one. Like the display in the museum that clusters diverse groups of political prisoners into a homogenous group of innocent victims of political violence, the representation of the 
gallows and death penalty opens space for the AKP as an embodiment of the voice of the oppressed and the liberator of the people.

In addition, there is an individualization of the inmates, an atomization that fits the atomistic nature attributed to the masses (Arendt, 1951) in the way prisoners are depicted. Tortures are portrayed as something that solely happened in the cells, and prisoners are shown to have faced the prison authorities individually. Nevertheless, the reality of solidarity and resistance is not narrated by the museum. As previously mentioned, populism presupposes an indistinct mass of people who have unmediated ties to the leader. As such, populism does not tolerate intermediary groups, civil or political societal groups (Weyland, 1996). In parallel with this, the former inmates of the Ulucanlar prison are also depicted as individuals who were victimized by the Republican political elites/ military establishment at the aggregate level. It suggests that it was only through the AKP government that such practices came to an end, as the museum's curator also told us in the quote earlier. Even though Turkey's current record on prison and human rights violations proves this wrong (Freedom House, 2020), telling the story in such a way provides the AKP with political leverage that helps advance its populist cause, as was the case in the 2010 referendum.

In addition to excluding the prisoners' political background, some other critical exclusions show the selective nature of the museum's narrative in light of political urgencies. A case in point is how the executions of Deniz Gezmiş, Hüseyin Inan, and Yusuf Aslan are told. The AKP's anti-establishment lineage is traced back by the party to the Democrat Party leader Menderes, whom the 1960 military intervention leaders executed. Menderes, like Erdoğan, situated himself as the voice of the periphery, and he is a figure that Erdoğan often speaks of favorably, to the point of depicting him as a martyr for democracy overlooking Menderes' authoritarianism-be it his brutal repression of dissent or his administration's role in the 1955 pogroms against non-Muslim minorities of Turkey. The Justice Party was the direct successor of the Democrat Party, and it was the leader of this party, Süleyman Demirel, who played a leading role in getting the death sentences of these three young revolutionaries approved in the parliament. Every year, on the anniversary of their death, social media is filled with images showing Demirel urging his party members to approve the parliament's death sentences by raising their hands. Yet this fact is conveniently erased from the story framing the executions as the military's sole act.

An even bigger exclusion concerns the recent history of Turkey, just before the AKP came to power. In response to the hunger strikes and protests in prisons across Turkey against the planned F-Type prisons, which would isolate inmates in cells of one to three prisoners, the state carried out operations that it later would call "Return to Life" operations. During these operations, 31 prisoners died, with many more being tortured and wounded. These incidents get a minor mention in the museum including a couple of newspaper clips, all narrated from the official line (Aysu, 2015). The museum therefore makes a clear distinction between the political prisoners of the 1970s and 1980s and the ones from the late 1990s and 2000s. The former is presented as acceptable and authentic, while the latter are not to be included. As Batuman (2011) notes, what happened in Ulucanlar in the later periods of the 1990s and early 2000s was too much for the AKP to confront. This omission shows us once more that the museum does not aim to come to terms with the past to prevent future repression by political authorities or torture in correctional officers' hands. As per the master-narrative, people are depicted as victims at the political and state establishment's hands only to be saved by the AKP. Advocacy for human rights or prison reform is not on the agenda of the museum.

The Ulucanlar Prison Museum does not come across as a place where the Republic was expected to come to terms with the past and ensure that political oppression was left behind and prisoners were ensured humane conditions. There are no comments, calls, or consciousness-raising events regarding prisons' current state in Turkey throughout the museum. One could argue that the prison serves as an entertainment theme or as kitsch in this museum. In our interview with Bayiksel, she 
mentioned that there are sometimes film-viewing activities for the visitors. She mentioned the names of some prison-themed movies shown in the museum. She also mentioned the museum's playlist, which consists of "prison songs" across the political spectrum. As can be seen, the prison serves as an empty signifier filled with a particular meaning in the AKP's populist project. Tortures, executions, and other maltreatments are deemed appropriate for museums, as phenomena of the past, to be remembered but not reflected on today.

The museum is also a living and dynamic project that gets updated in light of contemporary political events. A case in point is the initial inclusion and subsequent removal of Sirrı Süreyya Önder, a well-known filmmaker, from the museum collection. Önder's biography and picture were removed from the museum when he became an essential face in the political opposition against the AKP due to his political activities in the HDP and his involvement in the Gezi events.

In addition to the omission of names and events, the museumification of the prison also led to the erasure of significant elements of historical experience known only to those who have heard or read about them through the accounts of witnesses. In other words, the museum is not fulfilling its job as a witness of its past. Batuman (2011) gives us a good snapshot of the kind of interventions chipped away from the museum's authenticity:

"Today, the prison is in a state where the traces of what had happened are destroyed and sterilized, its 'dirt' and the terror have been turned into a spectacle. . Those who know a thing or two about the prison will look in vain for the small courtyard where executions took place. The walls forming the courtyard no longer exist as a result of the demolition of the refectory. The office of the prison director in which Deniz was seated to spend his last minutes watching the gallows where he was going to be executed is a kitchen now."

Such sterilization of the prison through its museumification and the homogenization of its inmates' victimhoods precisely speaks to the kind of populist agenda that the AKP regime has employed in its rhetoric and praxis.

What is at stake in the silences of Ulucanlar museum can be best understood in Mason and Sayner's (2019: 8) account of silences: "It is [. . .] always necessary to ask what account of silence are we judging the museum, display or exhibition against. If a particular exhibition was only ever set up as an entirely partisan private collection and is acknowledged as such, it may be anachronistic to point to silences in a historical record it was never aiming to redress. If, on the other hand, a museum makes a claim to be representing a nation or a community, then it is more legitimate to do so." Thus, given the national status of the Ulucanlar Museum and the authoritative voice it claims, it is only natural to demand representativeness from the museum, which in this case is never delivered.

\section{Conclusion}

Ulucanlar gives us important clues about how political projects, in this case, populist and revisionist ones, can repurpose artifacts and traumatic events of the past for current purposes. Unlike building new museums or mosques from scratch, this includes a negotiation of what is already there with the priorities of the political project at hand while simultaneously making use of the indexicality and "authenticity" of the historic site. The search for authenticity for the museum visitors and strategies of delivering such authenticity via different media by museum creators, and the potential for prosthetic memory through similar methods are issues discussed in the bodies of collective memory, museum and heritage literature as mentioned above. In this study, we take this dialogue further in these fields by illustrating how such techniques are instrumentalized in populist projects. The journey of the Ulucanlar Prison's museumification illustrates how a collective past can be instrumentalized for populist politics, on a quest for the extension of power, and silencing pluralism in the society to create a unilinear trajectory for the future. 


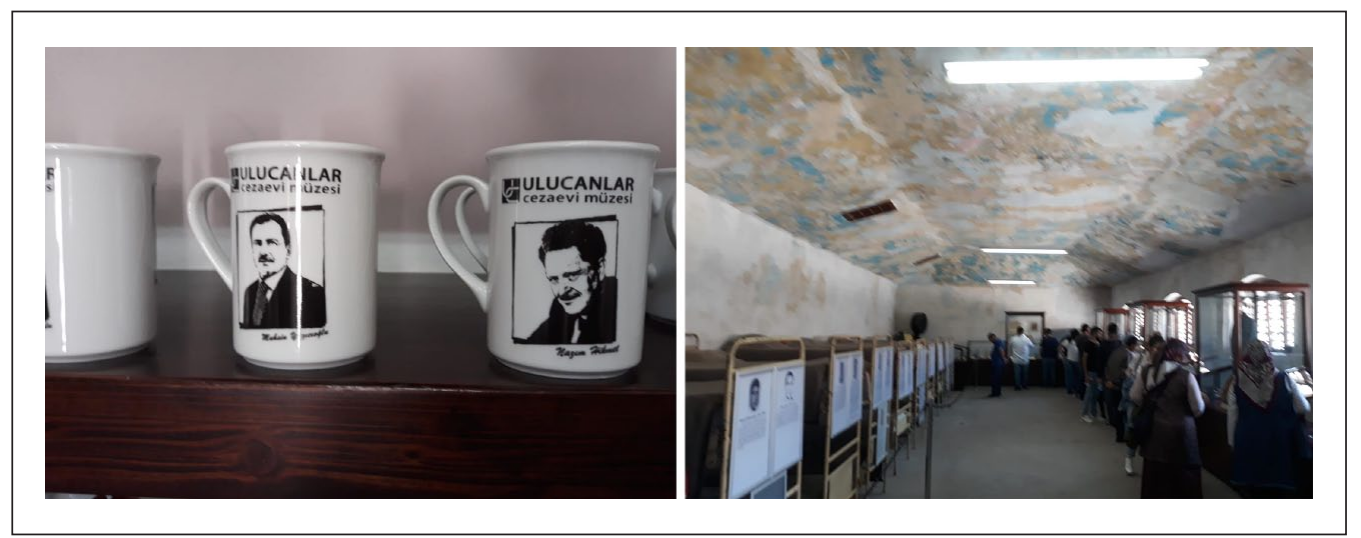

Figure 9. Mugs sold at the museum gift shop with the ultranationalist Muhsin Yazıcıoğlu and the communist poet Nazım Hikmet on them, among others.

Figure 10. Bunker beds displayed in the museum with short biographies of those who stayed attached in front of them.

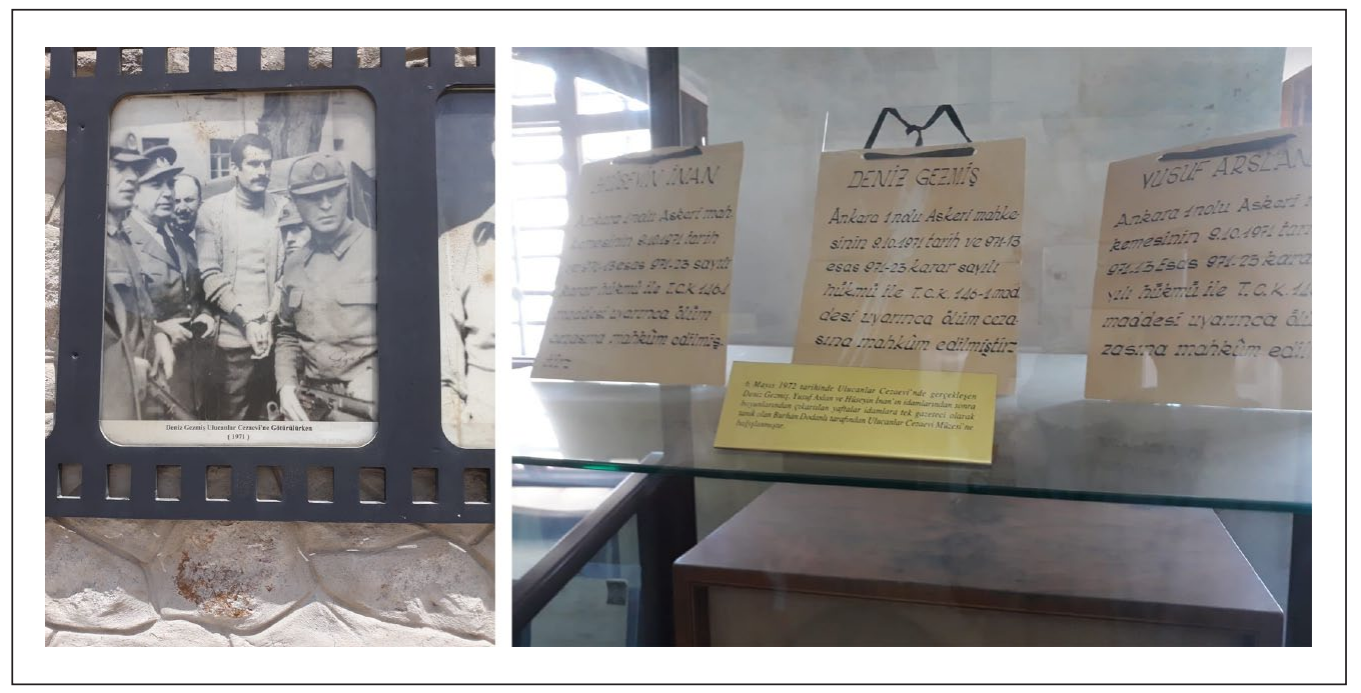

Figure I I. Picture showing Deniz Gezmiş captured.

Figure 12. Display of the labels hung on Gezmiş, Inan and Aslan at their executions stating the verdict upon which they were hanged.

As Walby and Piche (2015: 243-234) have argued, we need to be perceptive of the homogenizing role authenticating narratives play in museums, and this article has done so by showing how the museum's display and narrative structure urges visitors to get subsumed in the holistic populist narrative, not leaving room for the plurality of stories (and identities, for that matter) and does not open a space for critical engagements with current wrongdoings and human rights violations of the state and the penal system. The claims for authenticity made by the museum and the authority it 
claims by its very indexicality as the place in which the trauma actually took place may further reinforce the closure on debates regarding the past. Violi (2012: 70-71) reminds us about the trauma sites in Cambodia, Chile, and Italy:

in all three trauma sites there is a general lack of factual information and any other kind of instructional materials. As a result, it may become rather difficult to understand the historical, cultural and political network of reasons and causes that underlie these events, as well as their internal dynamics. All this is largely left up to the evocative power of the place itself, to its unique capacity for bringing events of the past forward into our present time by way of its indexical links with what happened. But emotional evocation is something quite different from deep understanding. In this sense the power of indexicality as a signifying device may become a limit, a sort of mono-dimensional enclosure system, lacking any active links to the wider historical, cultural and political context that produced the traumatic event.

When we add to this the narratological molding of the museum that is framing visitors' experiences of the past as one of oppression only to be saved by AKP, we can see that the populist project further closes the potential for pluralism and a more multifaceted and critical engagement with the past. The museum experience at Ulucanlar can then be likened to a dance with the populist, in which the populist leads and people are asked to identify, instead of understanding or critically engaging.

Ulucanlar is not a singular case in the efforts of the AKP rule in appropriating historical sites and events and memorializing in line with their own ideological blueprint. Using the past is an art that the AKP has mastered in its approximately two decades of uninterrupted single-party rule in Turkey. As the more recent monuments, museums, and speeches of the AKP politicians and their supporters in the media, civil society, bureaucracy, and other realms show, the refashioning of Turkish history, both distant and recent, lies at the center of the AKP's populism. In contrast to the more over-the-top populism and friend-enemy distinction of the later periods for example, the commemoration of July 15, 2016, the failed coup attempt, the case of Ulucanlar presents a more covert populism of the relatively earlier periods of the AKP rule before it captured the state institutions and when its targets were the state elites, namely the courts and the military. Whereas in the latter ones there is a strong emphasis on internal and external enemies, and the "people's will" is pronounced much more forcefully and defined in exclusionary terms, Ulucanlar is framed as a place that could speak for the entire population across the political spectrum. This broad and supposedly nonpartisan stance of Ulucanlar also stands in contrast to panoramic display devised by the AKP, such as the Panorama 1453 Museum commemorating Istanbul's conquest. Panorama 1453 seems to further narrow the meaning available for the audience by imposing an immersive panoramic depiction of the past as a singular story glorifying the Ottoman, Islamic past, and juxtaposing it with the Kemalist nation-building project that tried to cut ties with the Ottoman era (Bozoğlu, 2020a, 2020b). However, upon scrutiny, one recognizes that this seemingly more inclusive and democratic depiction is a façade. Ulucanlar becomes the victim of a political project that hijacks multiple stories and traumas and molds them in its singular populist image.

The memory discourse adopted in the later stages of the AKP rule (once it captured state institutions and had less to say about economics given the diminishing performance in that field) reveals more overt attempts at bending history to further their Manichean, populist cause. In this era, neoOttomanism, based on Islamist themes and the nostalgia for the Ottoman past, becomes the kernel of the AKP's domestic and foreign policy. As Kaya et al. (2020) and Kaya and Tecmen (2019) also show, in that context, Islamism and neo-Ottomanism are merged under a populist project as evident in TV series, state ceremonies, naming of places and streets, among others. The museumification of Ulucanlar happened at a relatively early stage in the AKP's term, in which it was still eager to 
assert itself as a progressive and liberal democratic force. However, as our analysis has shown, "coming to terms with the past" framework was mere disguise. Underneath this, the AKP was already defining the deserving citizen, whose story is to be remembered as the voice of the "authentic" people. What is more, one can argue that the AKP's commemorative practices following the 2016 coup attempt, with the martyrdom and democracy tropes surrounding the resistance against the coup, still show themes that are experimented with in the Ulucanlar Prison, albeit in a more Islamist, inward-looking, polarizing, and explicitly exclusionary fashion.

The framing of the past for such counter-hegemonic struggles also provides significant insights into the difficulty of the framing of "coming to terms with the past." In the case of Ulucanlar, what was framed as such by the main actors of the museumification process, turned out to be instrumentalization of the past for a singular political agenda — conveniently removing past's complexities and pluralism for narrating a politically useful story in the AKP's effort to further its popular appeal and legitimize extension of its power. This point brings us to the issue of how we should treat "coming to terms with the past" as a phenomenon outside its immediate European context. Instead of serving the creation of a more conscientious and pluralistic society that takes ethical responsibility for the consequences of its actions, in the hands of populists, "coming to terms with the past" can be used to silence opposition and expand executive power with the moral high ground obtained by discursively employing this very phenomenon. Ironically then, a concept developed to bolster constitutionalism and democracy is used to erode them. As Connerton (2008: 60) observes, the analysis also proves that repressive forgetting can also happen covertly without apparent violence. A closer look at the underlying details of the apparently progressive revisiting of past traumas reveals repression of complex events of the past for the sake of an authoritative populist master narrative.

Our findings are in line with the ones of Traverso (2019: 15-16), who criticizes the fact that the history of World War II, including the history of anti-fascist resistance, has been reduced to the victim/oppressor model and the wrongdoings of the era are relegated to the past. Traverso (2019: 90-91), talking about the central role the Holocaust has come to play in the Western, particularly American memory, warns us about the pitfalls of this discourse of remembrance. He argues that these commemorations have turned into justifications of present political actions. Perhaps more importantly, such commemorations, instead of paving the way for more critical thinking toward our contemporary world, have turned into vindications of the powerful's status quo. Against these, Traverso reminds us of the Frankfurt School's messages, particularly about the fact that the wrongdoings of the Nazi past are not alien to our current world or modernity but can instead only be understood as embedded in our world.

With Traverso, we share the concerns regarding the problematic nature of seeing history's wrongdoings as a thing of the past. In Ulucanlar's case, while it may seem commendable that the museum depicted tortures and suppression of dissent, the narration of the story transposes these as a theme of the past, dealt with and not to be critical of today. This point is made evident by the museum curator's comments claiming that people are no longer imprisoned for their views in Turkey even though Turkey has a worrisome record of human rights violations, including the onslaught on the media, unlawful detentions currently, and current laws in place, such as Article 301, make the persecution of expression of opinion possible.

This observation calls for the necessity for opening a discussion and an invitation to be alert against current challenges to democracy, human rights, and human beings' dignity. In other words, it calls for an empathetic, universal, plural approach to memory. To do this, institutional rearrangements are necessary that would take away museums from the tutelage of governments and provide more autonomy for the narration of the past. What is needed is a museum that lets the people speak and not speak in their name, which lies at the heart of the problem of populism. Such a project 
would entail balancing civic involvement, pluralistic practices, and participatory processes with state-funding and coordination to make museums more polyvocal without risking the domination of museums and collective memory by certain societal actors at the expense of others. ${ }^{9}$ Such practices are possible to be imagined in democracies yet much harder, if not impossible, to be attained under increasingly authoritarian rules such as the one experienced in contemporary Turkey. As it stands, the Turkish case can be viewed as a forewarning or a magnifying glass for the collective memory-populism nexus. Lessons learned from this case can be put to practice in the design of polyvocal museums elsewhere without succumbing to the moralizing unilinear and single-dimensional stories of the past told by populist politicians and their allies.

\section{Acknowledgements}

The authors are grateful for the insightful comments of Bülent Batuman, Daniel Just, Kürşat Çınar, Ayşe Ayata, Aslı Çırakman, Başak Alpan, and the three anonymous reviewers of Memory Studies on the previous drafts of this article. Berat Uygar Altınok's contribution to this article is based on his dissertation research at Bilkent University.

\section{Funding}

The author(s) received no financial support for the research, authorship, and/or publication of this article.

\section{ORCID iD}

Meral Ugur-Cinar (iD) https://orcid.org/0000-0002-2195-4861

\section{Notes}

1. Savage (2012) and Bull (2016) are exceptions in pointing at how populist politicians use the past to create friend-enemy distinctions, showing how right-wing populists have used the history of their countries, Italy and the US respectively, in order to frame the Left as existential enemies of the people and in filling empty signifiers such as "socialists" with negative meaning. For recent studies addressing the link between populism and national heritage, see (De Cesari and Kaya, 2019) and (Kaya, 2020).

2. See, e.g. Aslanidis (2016), Barr (2009), Filc (2010), Gidron and Bonikowski (2013), Mudde (2004), Mudde and Kaltwasser (2018), and Weyland (1996).

3. On the detrimental effects of populism to the quality of democracy, see for example Arato (2013), Cohen (2019), De la Torre (2019), and Urbinati (2013).

4. On museums and collective memory, see, for instance, Bennett $(1995,2017)$ and Hooper-Greenhill (1994).

5. On how Ankara became a playground of this hegemonic struggle through monuments and architecture, see also Sargin (2004).

6. It appears that in the initial stages it was mostly the commercial and touristic priorities of the municipal government that led to disagreements. In the age of neoliberalism, which means fewer budgets from the central state to the municipal governments, local governments keep such considerations along with the political ones, as this case demonstrates. This mentality is also in line with the AKP's as the post-2002 AKP era of political Islam can best be understood within the context of the "increasing dominance of neoliberal accumulation strategies over Islamist ideological inclinations" (Batuman, 2013: 585).

7. On the quest for authenticity in touristic settings (see, e.g. MacCannell, 1973, 2008; Prentice, 2001).

8. Notable exceptions are Fethi Gürcan and Talat Aydemir, both military officers, who were executed upon plotting a coup. The museum and the printed sources by the museum, do not dwell on any representation of victimhood in their cases since they were coup perpetrators. While their names repeatedly show up, representation is devoid of implied innocence.

9. Such balances are similarly sought after in other areas of political science, public policy and governance (see e.g. Fung and Wright, 2003; Hirst, 2000). 


\section{References}

Arato A (2013) Political theology and populism. Social Research 80(1): 143-172.

Arendt H (1951) The Origins of Totalitarianism. New York: Harcourt Brace and Co.

Art D (2006) The Politics of the Nazi Past in Germany and Austria. New York: Cambridge University Press.

Aslanidis P (2016) Is populism an ideology: A refutation and a new perspective. Political Studies 64(1): $88-104$.

Assmann J (1995) Collective memory and cultural identity. New German Critique 65: 125-133.

Aysu T (2015) Turning Ulucanlar prison into Ulucanlar prison museum: The politics of creating a memory place. Master Thesis, İstanbul Bilgi University, Turkey.

Aytaç SE and Elçi E (2019) Populism in Turkey. In: Stockemer D (ed.) Populism around the World: A Comparative Perspective. Cham: Springer, pp.89-108.

Bakiner O (2018) A key to Turkish politics? The center-periphery framework revisited. Turkish Studies 19(4): 503-522.

Barr RR (2009) Populists, outsiders and anti-establishment politics. Party Politics 15(1): 29-48.

Barthes R (1981) The discourse of history. Comparative Criticism 3: 7-20.

Batuman B (2011) Ulucanlar Cezaevi Muzesi, 26 June. Available at: http://www.radikal.com.tr/radikal2/ ulucanlar-cezaevi-muzesi-1054190/ (accessed 7 July 2020).

Batuman B (2013) City profile: Ankara. Cities 31: 578-590.

BBC Turkish (2017) 2010 referandumu: 'Evet', 'Hayır' ve 'Boykot' cepheleri ne demişti?, 5 April 2017, https://www.bbc.com/turkce/haberler-turkiye-39462061

Bennett T (1995) The Birth of the Museum: History, Theory, Politics. New York: Routledge.

Bennett T (2017) Exhibititon, truth, power: Reconsidering "the exhibitionary complex". In: Latimer Q and Szymczyk A (eds.) The Docmenta 14 Reader. Munich: Prestel, pp.339-352.

Birgun (2020) 'Dindar nesil' projesi neden gençler üzerinde etkili olamadı? 11 May 2020, https://www.birgun.net/haber/dindar-nesil-projesi-neden-gencler-uzerinde-etkili-olamadi-300486.

Bozoğlu G (2020a) Museums, Emotion and Memory Culture: The Politics of the Past in Turkey. London: Routledge.

Bozoğlu G (2020b) 'A great bliss to keep the sensation of the conquest': The emotional politics of the Panaroma 1453 Museum in İstanbul. In: De Cesari C and Kaya A (eds.) European Memory in Populism: Representation of Self and Other. London: Routledge, pp. 91-111.

Bull AC (2016) Modern Italy: A Very Short Introduction. Oxford: Oxford University Press.

Cengizkan A and Cengizkan NM (2019) Bir Şehir Kurmak: Ankara 1923-1933. Ankara: VEKAM.

Cohen JL (2019) Populism and the politics of resentment. Jus Cogens 1: 5-39.

Connerton P (2008) Seven types of forgetting. Memory Studies 1(1): 59-71.

De Cesari C and Kaya A (eds.) (2019) European Memory in Populism: Representations of Self and Other. London: Routledge.

De la Torre C (2019) Is left populism the radical democratic answer? Irish Journal of Sociology 27(1): 64-71.

Doroll C M (2015) The Spatial Politics of Turkey's Justice and Development Party (AK Party): On Erdoğanian New Ottomanism, unpublished PhD. Thesis (University of Arizona).

Eyerman R (2004) The past in the present: Culture and the transmission of memory. Acta Sociologica 47(2): $159-169$.

Filc D (2010) The Political Right in Israel: Different Faces of Jewish Populism. London: Routledge.

Freedom House (2020) Freedom in the World 2020: Turkey. Available at: https://freedomhouse.org/country/ turkey/freedom-world/2020 (accessed 7 July 2020).

Fung A and Wright EO (2003) Thinking about empowered participatory governance. In: Fung A and Wright EO (eds) Deepening Democracy: Institutional Innovations in Empowered Participatory Governance. London: Verso Press, pp.3-45.

Gidron N and Bonibowski B (2013) Varieties of populism: Literature review and research agenda. Working Paper Series, Weatherhead Center for International Affairs 13(4): 1-39.

Haberturk (2010) Başbakan Erdoğan Ağladı. Haberturk, 20 July 2010. https://www.haberturk.com/gundem/ haber/534140-basbakan-erdogan-agladi 
Hirst P (2000) Democracy and governance. In: Pierre J (ed.) Debating Governance. Oxford: Oxford University Press, pp.13-36.

Hooper-Greenhill E (1994) The Educational Role of the Museum. London: Routledge.

Kansteiner W (2002) Finding meaning in memory: A methodological critique of collective memory studies. History and Theory 41(2): 179-197.

Kaya A (2020) Populism and Heritage in Europe Lost in Diversity and Unity. London: Routledge.

Kaya A and Tecmen A (2019) The use of the past in populist political discourse: Justice and development party rule in Turkey. In: de Cesari C and Kaya A (eds) European Memory in Populism: Representations of Self and Other. London: Routledge.

Kaya A, Robert MV and Tecmen A (2020) Populism in Turkey and France: nativism, multiculturalism and Euroskepticism. Turkish Studies 21(3): 361-391.

Koç YT and Yavuz D (2010) Tevkifhaneden Müzeye: Ulucanlar. Ankara: Rıhtım Ajans.

Laclau E (2005) On Populist Reason. London; New York: Verso.

Landsberg A (2004) Prosthetic Memory: The Transformation of American Remembrance in the Age of Mass Culture. New York City: Columbia University Press.

MacCannell D (1973) Staged authenticity: Arrangement of social space in tourist settings. American Journal of Sociology 79(3): 589-603.

MacCannell D (2008) Staged authenticity today, In: Sorkin M (ed.) Indefensible Space: The Architecture of the National Insecurity State. London: Routledge, pp. 259-76.

MacCannell D (2013) The Tourist: A New Theory of Leisure Class. Berkeley, CA: University of California Press

Mardin Ş (1973) Center and periphery relations: A key to Turkish politics? Daedalus 102: 169-190.

Mason R and Sayner J (2019) Bringing museum silence into focus: Eight ways of thinking about silence in museums. International Journal of Heritage Studies 25(1): 5-20.

Mimdap (2012) Bir Mimarlık Etkinliği olarak Ulucanlar Cezaevinin Müzeye Dönüşüm Serüveni, 1 October. Available at: http://mimdap.org/2012/10/ulucanlar-cezaevini-muzeye-donuthturulme-sureci-dedherlendirelim/ (accessed 7 July 2020).

Mouffe C (2018) For a Left Populism. London: Verso.

Mudde C (2004) The populist zeitgeist. Government and Opposition 39(4): 541-563.

Mudde C and Kaltwasser CR (2018) Studying populism in comparative perspective: Reflections on contemporary and future research agenda. Comparative Political Studies 51(13): 1667-1693.

Müller JW (2016) What is Populism? London: Penguin Books.

Nora P (1989) Between memory and history: Les Lieu de Mémorie. Representations 26: 7-24.

Olick JK (1999) Collective memory: The two cultures. Sociological Theory 17(3): 333-348.

Öniş Z (2015) Monopolising the Centre: The AKP and the uncertain path of Turkish democracy. The International Spectator 50(2): 22-41.

Özbudun E (2013) Party Politics and Social Cleavages in Turkey. Boulder, CO: Lynne Rienner Publishers.

Prentice R (2001) Experiential cultural tourism: Museums \& the marketing of the new romanticism of evoked authenticity. Museum Management and Curatorship 19(1): 5-26.

Sargin GA (2004) Displaced memories, or the architecture of forgetting and remembrance. Environment and Planning D: Society and Space 22(5): 659-680.

Savage R (2012) From McCarthyism to the Tea Party: Interpreting Anti-Leftist Forms of US Populism in Comparative Perspective. New Political Science 34(4): 564-584.

Thurston H (2016) Prisons and Punishment in Texas: Culture, History and Museological Representation. London: Palgrave Macmillan.

TMMOB Mimarlar Odası Ankara Şubesi (2010) Kent Düşleri 1- Projefikir Ulucanlar Merkez Kapalı Cezaevi Değerlendirme Projesi. Ankara: TMMOB Ankara Şubesi.

Traverso E (2019) Geçmişi Kullanma Kılavuzu-Tarih, Bellek, Politika. İstanbul: İletişim Yayınları.

Urbinati N (2013) The populist phenomenon. Raisons Politiques 3: 137-154.

Violi P (2012) Trauma site museums and politics of memory: Tuol Sleng, Villa Grimaldi and the Bologna Ustica museum. Theory, Culture and Society 29(1): 5-75. 
Walby K and Piche J (2015) Staged authenticity in penal history sites across Canada. Tourist Studies 15(3): 231-247.

Wertsch JV (2000) Narratives as cultural tools in sociocultural analysis: Official history in soviet and postsoviet Russia. Ethos 28(4): 511-533.

Wertsch JV and Roediger HL III (2008) Collective memory: Conceptual foundations and theoretical approaches. Memory 16(3): 318-326.

Weyland K (1996) Neopopulism and neoliberalism in Latin America: Unexpected affinities. Studies in Comparative International Development 31: 3-31.

White HV (1973) Metahistory: The Historical Imagination in Nineteenth-Century Europe. Baltimore, MD: Johns Hopkins University Press.

White HV (1978) Tropics of Discourse: Essays in Cultural Criticism. Baltimore, MD: Johns Hopkins University Press.

White HV (1990) The Content of the Form. Baltimore, MD: The Johns Hopkins University Press.

Yalım I (2002) Ulus Devletin Kamusal Alanda Meşruiyet Aracı: Toplumsal Belleğin Ulus Meydanı Üzerinden Kurgulanma Çabası. In: Sargın GA (ed.) Başkent Üzerine Mekan-Politik Tezler: Ankara'nın Kamusal Yüzleri. Istanbul: Iletişim Yayınları, pp.9-40.

Zerubavel Y (1995) Recovered Roots: Collective Memory and the Making of Israeli National Tradition. Chicago, IL and London: University of Chicago Press.

\section{Author biographies}

Meral Ugur-Cinar is Assistant Professor at Bilkent University. She is the author of the book Collective Memory and National Membership: Identity and Citizenship Models in Turkey and Austria and many articles and book chapters on subjects including collective memory, political identity, political institutions, political narratives, political regimes, social movements, and gender, among others.

Berat Uygar Altınok is PhD Candidate in Political Science Department at Bilkent University. He received his MA degree in Social \& Political Thought from Central European University in 2015. His research centers on populism, collective memory, and ideology. 